\title{
Electrooxidation of the Reactive Orange 16 Dye Using Boron Doped Diamond and DSA Type Electrodes
}

Fernanda L. Migliorini, Marcela D. Alegre, Suellen A. Alves, Marcos R. Lanza, Mauricio R. Baldan and Neidenei G. Ferreira

ECS Trans. 2012, Volume 43, Issue 1, Pages 89-96.

doi: $10.1149 / 1.4704944$

Email alerting

Receive free email alerts when new articles cite this article - sign up in the service box at the top right corner of the article or click here 


\title{
Electrooxidation of the Reactive Orange 16 Dye using Boron Doped Diamond and DSA $^{\circledR}$ Type Electrodes
}

\author{
F.L. Migliorini ${ }^{\mathrm{a}}$, M.D. Alegre ${ }^{\mathrm{a}}$, S.A. Alves ${ }^{\mathrm{b}}$, M.R.V. Lanza ${ }^{\mathrm{b}}$, M.R. Baldan ${ }^{\mathrm{a}}$ and N.G. \\ Ferreira $^{\mathrm{a}}$ \\ ${ }^{a}$ Instituto Nacional de Pesquisas Espaciais, São José dos Campos, Brasil.

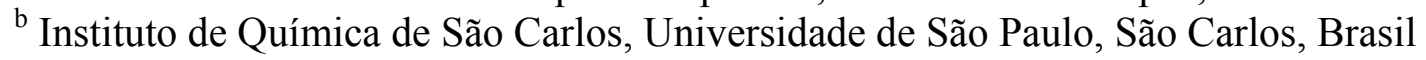

The comparison of the efficiencies for boron-doped diamond (BDD) and for DSA-Cl ${ }_{2}{ }^{\circledR}$ type electrodes to degrade the reactive orange 16 (RO16) dye is presented. The results for the dye electrochemical degradation were investigated by spectroscopic techniques UV/VIS analysis, Total Organic Carbon (TOC), and High Performance Liquid Chromatography (HPLC). The BDD electrode showed the higher performance in the whole range of current densities studied for the color removal as well as in the mineralization of organic materials present in such dye.

\section{Introduction}

Several studies have been conducted to develop technologies for the treatment of organic contaminants since it is a global problem due the economy and population growth $(1,2)$. The electrochemical methods appear very promising because they offer a simple and relatively inexpensive methodology, using a clean reagent (electron). Therefore, the investigation of new anode material for the electrooxidation of pollutants may provide better efficiency to this process $(3,4)$.

These anode materials can be classified into electrodes active or not active. In the called active electrodes, the oxidation of the organic molecule occur by the formation of higher oxides $\left(\mathrm{MO}_{\mathrm{x}+1}\right)(5)$. Or else, when the organic species is directly oxidized by the adsorption of hydroxyl radicals, they are called non-active electrodes. The DSA-Cl ${ }_{2}{ }^{\circledR}$ (dimensionally stable anodes) type electrodes are classified as active electrodes and are known due to their properties to electrochemical degradation. Several studies have been reported in the literature for electrochemical degradation using $\mathrm{DSA}-\mathrm{Cl}_{2}{ }^{\circledR}$ electrodes, such as pesticides (6), and dyes $(7,8)$, among others.

On the other hand, boron doped diamond (BDD) electrodes are classified as non-active (9). The electrochemical studies of this material started in the 80 ' by Pleskov and coworkers (10). The growth of boron doped diamond films has been performed on various substrates such as, silicon, titanium, niobium and others with success (11-13). BDD electrode has several properties that differ from other conventional materials such as: wide potential window in aqueous and nonaqueous electrolytes, corrosion stability, low capacitive currents and high chemical and electrochemical inertness. These characteristics provide high electrosynthesis efficiency, large application in wastewater treatment and electroanalytical detection. Particularly, for wastewater treatment, these electrodes promote a large production of hydroxyl radicals $(\cdot \mathrm{OH})$ from the water discharge, which are weakly adsorbed on the electrode surface, leading to the mineralization of organic pollutants $(14,15)$. 
Among the pollutants, the textile dyes deserve special attention. They are dropped into water courses without treatment or are treated by methods such as biological, which in most cases do not present satisfactory results, even for the color removal (16). These dyes are highly soluble in water and have low levels of attachment to the fibers. Their molecules are formed from a system of aromatic rings linked by at least one chromophore group $(-\mathrm{N}=\mathrm{N}-)$, primarily responsible for the color of the dye, which are resistant to natural degradation in addition to possessing mutagenic and carcinogenic character (17). This work aims to compare the electrooxidation of the reactive orange 16 (RO16) dye using BDD grown on titanium substrate (BDD/Ti) and the commercial $\mathrm{DSA}-\mathrm{Cl}_{2}{ }^{\circledR}$ electrodes. The efficiency of the electrodes in the process of dye degradation was analyzed under different current densities, using analytical techniques such as spectroscopy of the UV-Vis, high performance liquid chromatography (HPLC) analysis and total organic carbon (TOC) measurements.

\section{Experimental Procedure}

$\underline{\text { Preparation and Characterization of BBD electrodes and electrode type DSA-Cl }} \underline{2}_{2}$

Hot filament chemical vapor deposition (HFCVD) technique was used to produce electrodes formed from plate-shaped $\mathrm{Ti}$ substrates recovered with $\mathrm{BDD}$ films. This $\mathrm{BDD} / \mathrm{Ti}$ electrode with the dimensions of $(25 \times 25 \times 0.7 \mathrm{~mm})$ was prepared from a standard gas mixture consisting of $99 \%$ of $\mathrm{H}_{2}$ and $1 \%$ of $\mathrm{CH}_{4}$, with a deposition time of $7 \mathrm{~h}$ (E1). The temperature and pressure inside the reactor chamber were kept at $650{ }^{\circ} \mathrm{C}$ and 40 Torr, respectively. The doping control was obtained from an additional $\mathrm{H}_{2}$ gas flux passing through a bubbler containing a solution of $\mathrm{B}_{2} \mathrm{O}_{3}$ dissolved in $\mathrm{CH}_{3} \mathrm{OH}$ with the $\mathrm{B} / \mathrm{C}$ ratio of $15.000 \mathrm{ppm}$. This additional hydrogen flow into the reactor was controlled by a rotameter which was maintained at $40 \mathrm{sccm}$ during the film deposition. The DSA-Cl ${ }_{2}{ }^{\circledR}$ electrode Commercial $\left(\mathrm{Ti} / 30 \mathrm{RuO}_{2}-70 \mathrm{TiO}_{2}\right)$ was produced by De Nora do Brazil Ltda (E2). Top view scanning electron microscopy (SEM) images of BDD film were obtained from a Jeol equipment JSM-5310. The quality of BDD film was analyzed from Micro-Raman spectra recorded by a Renishaw microscope system 2000 in backscattering configuration.

\section{Condition Monitoring and Degradation of the RO16 Dye}

The electrochemical degradation of a degassed solution of the RO16 azo-dye supplied by Aldrich $(\sim 50 \% \mathrm{~m} / \mathrm{m})$ was performed in a polypropylene home-made single cell with capacity of $0.45 \mathrm{~L}$. The BDD/Ti working electrode $\left(\sim 4.15 \mathrm{~cm}^{2}\right.$ of geometric area) was located at the bottom of the cell. Platinum screen, $2 \mathrm{~cm}$ in diameter, was used as a counter electrode and a commercial $\mathrm{Ag} / \mathrm{AgCl}$ electrode $\left(3.0 \mathrm{~mol} \mathrm{~L}^{-1} \mathrm{KCl}\right.$ solutions) as the reference electrode. All the degradation assays were performed at $20{ }^{\circ} \mathrm{C}$ and constant stirring. The solutions with $50 \mathrm{mg} \mathrm{L}^{-1}$ of the $\mathrm{RO} 16$ azo-dye in a $\mathrm{K}_{2} \mathrm{SO}_{4} 0.1 \mathrm{~mol} \mathrm{~L}^{-1}$ (Synth) $+\mathrm{H}_{2} \mathrm{SO}_{4} 0.1 \mathrm{~mol} \mathrm{~L}^{-1}$ (Synth) supporting electrolytes were electrolyzed at different current densities of 25, 50,75, 100, 150 e $200 \mathrm{~mA} \mathrm{~cm}^{-2}$ and at 10, 20, 30, 45, 60,75 and 90 min periods for each current density. These procedures were adopted for both E1 and E2 electrodes. All electrochemical measurements were carried out using a potentiostat/galvanostat AUTOLAB model PGSTAT 302 (Eco Chimie) coupled with a BRTS-10A current booster, controlled by the GPES software. The RO16 azo-dye electrochemical degradation was monitored by: (1) UV-Visible (UV/VIS) 
Espectrophotometry (Varian Cary 50 Scan Espectrophotometer 300 a $600 \mathrm{~nm}$ ); (2) RO16 azo-dye concentration (HPLC, Shimadzu, modelo 20 A, with UV/VIS SPD-20 detector, C18 $\left(250\right.$ x 4,6 mm) Shimadzu ShimPack CLC-ODS ${ }^{\circledR}$ collum, methanol: ammonium acetate (70:30), $0,8 \mathrm{~mL}$ min-1 flux and UV/VIS detector at $\lambda=254 \mathrm{~nm}$; and (3) total carbon organic (TOC, Shimadzu TOC-VCPN analyzer).

\section{Results and discussion}

\section{Morphological and Structural Characterization of Diamond Electrode}

The top view SEM image of the BDD/Ti electrode is shown in Figure 1 (A). The image shows a continuous and homogeneous film covering the whole substrate without presence of delamination or cracks. Considering the diamond/Ti interface, this is an indicative of its high adherence. This result is very important because the diamond growth on Ti substrates presents two problems. The one is concerning the difference of the thermal expansion coefficients between Ti and diamond. The other is related to the formation of intermediate phases such as hydride and titanium carbide. These factors together weaken the samples and are responsible for the formation of cracks and delaminations in diamond films (18).

To investigate the quality of the BDD film (E1), Raman scattering spectrum is shown in Figure 1 (B). The Raman peak in the region of $1332 \mathrm{~cm}^{-1}$, which corresponds to the first order vibration of the diamond (19). We also observed the emergent band at 1220 $\mathrm{cm}^{-1}$, characteristic of BDD films, that is attributed to the induced disorder in the diamond lattice due to the boron incorporation (20). This band increases significantly with increasing the doping level associated to a drastic reduction in the diamond peak. This process is assigned to the relaxation of selection rule $\mathrm{k}=0$ of Raman scattering due to the presence of a very high concentration of boron in the diamond lattice (21). The band around $1580 \mathrm{~cm}^{-1}$ can be attributed to band $\mathrm{G}$ (graphitic phases). The appearance of a band around $500 \mathrm{~cm}^{-1}$ is also observed, attributed to the vibration of boron pairs in the diamond lattice (20).
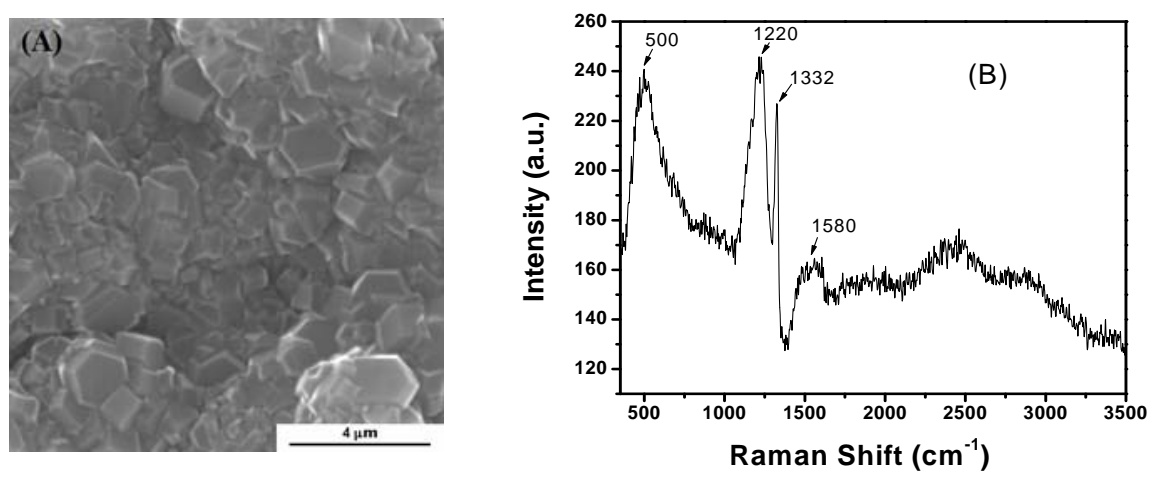

Figure 1. SEM image (A) and Raman spectrum (B) of the BDD/Ti film.

Electrochemical degradation of the RO16 dye with BDD/Ti and DSA ${ }^{\circledR}$ electrodes

\section{$\underline{\mathrm{UV} / \mathrm{VIS} \text { analysis }}$}

To evaluate the E1 and E2 efficiencies an important parameter is the color removal during the degradation process of this species. The RO16 dye presents two bands of 
absorption in the visible spectrum. The first, at around $390 \mathrm{~nm}$, may be associated with the $\pi-\pi^{*}$ transitions of the aromatic rings and the other, at around $500 \mathrm{~nm}$, is attributed to the $n-\pi^{*}$ transitions of the chromophoric $(-\mathrm{N}=\mathrm{N}-)$ azo group, present in the RO16 molecule. Thus, the color removal of the solution containing the dye, resulting from the reaction of the chromophore groups of the molecule, can be monitored from the intensity variation of these main absorption bands. Figure 2 shows the absorption spectra for both electrodes from 300 to $600 \mathrm{~nm}$ for the RO16 solutions electrolyzed at current density of $200 \mathrm{~mA} \mathrm{~cm}^{-2}$, respectively, for seven electrolysis times between 10 and $90 \mathrm{~min}$. For the electrode E1, a reduction in the intensities of two absorption bands as a function of the electrolysis time is observed. After 20 min of treatment, the solution was already colorless. Nonetheless, the electrode E2, in the same experimental conditions, failed to remove the color of the solution and it was not possible to observe the decay of two absorption bands in the visible region. This result is an indicative of the better efficiency of the electrode $\mathrm{E} 1$ for the dye color reduction.
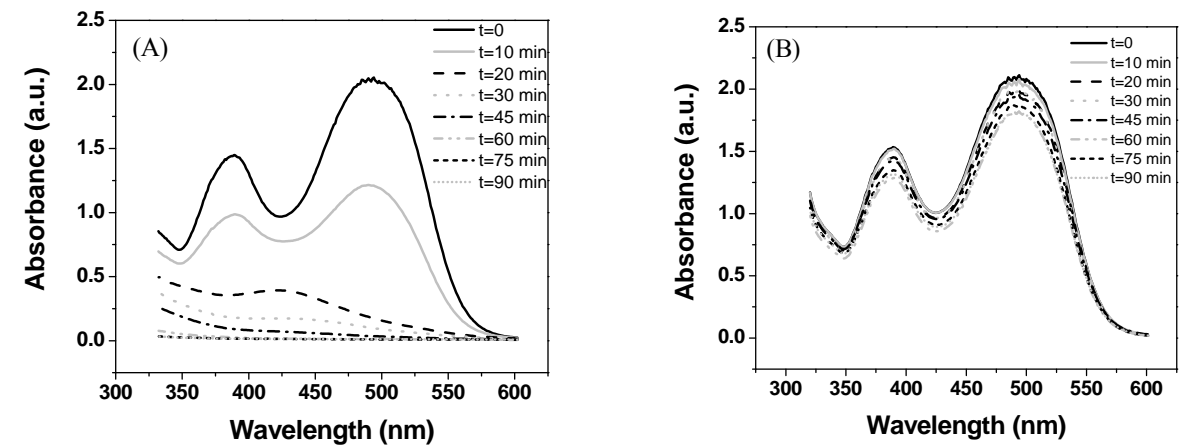

Figure 2. Absorption spectra of solutions of RO16 at $200 \mathrm{mAcm}^{-2}$ with the electrodes (A) $\mathrm{BDD}$ and (B) DSA-Cl ${ }_{2}{ }^{\circledR}$ as a function of electrolysis time.

For quantitative results, we used the maximum wavelength at $388,38 \mathrm{~nm}$ and a calibration curve to calculate the dye concentrations. The tests were conducted at various current densities ranging in 75, 100, 150 and $200 \mathrm{~mA} \mathrm{~cm}^{-2}$ for both electrodes E1 and E2. The results of the concentration decrease of the electrolyzed solutions are shown in Figure 3 (A), only for electrode E1. The dye concentration decreased as a function of electrolysis time, where the electrode E1 reached the removal of approximately $100 \%$ of the initial concentration in $60 \mathrm{~min}$. The decay of the concentration of RO16 dye with the DSA-Cl ${ }_{2}^{\circledR}$ electrode was only $10 \%$ after 90 min of electrolysis using the highest current density studied. 

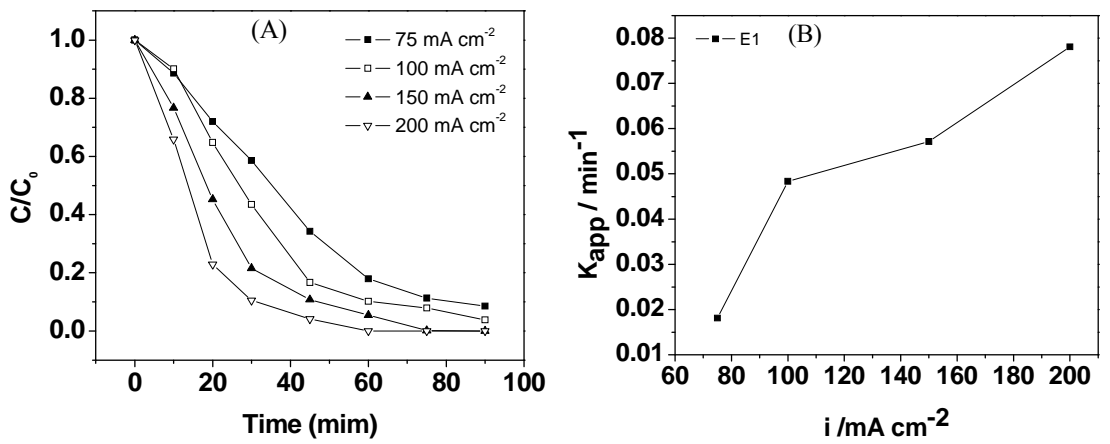

Figure 3. (A) Decay curves of the concentration of RO16 in different times depending on the applied current density (electrode BDD), (B) Kinetic constant variation from RO16 azo-dye electrodegradation process as a function of the applied current density for BDD.

The exponential profile of the RO16 azo-dye absorbance curves as a function of the time point to a pseudo-first order kinetic for the reactions involved in the electrodegradation of this colorant. The apparent kinetic constant $\left(\mathrm{k}_{\mathrm{app}}\right)$ can be linked to the dye concentration by the equation 1(22):

$$
\ln \frac{[\text { Corante }]}{[\text { Corante }]_{0}}=-k_{\text {app }} t
$$

Figure 3(B) shows the apparent rate constants as a function of current density applied only to the diamond electrode. The kinetic constant increases with increasing the current density. For the commercial DSA-Cl ${ }_{2}{ }^{\circledR}$ electrode, the values of the rate constants were not obtained because only a drop of $10 \%$ of the dye initial concentration was observed at $200 \mathrm{~mA} \mathrm{~cm}^{-2}$ after $90 \mathrm{~min}$ of electrolysis time. Therefore, the efficiency of BDD is so superior to the DSA for this process that this comparison was not possible using similar experimental conditions.

\section{$\underline{\text { TOC Measurements }}$}

TOC analyses were used to quantify the organic load present at the end of the processes of RO16 dye electrochemical degradation. This analysis is an indicative of the efficiency of the electrochemical process to mineralize the organic matter present in the dye solution. Among the pollution problems, the toxicity is due to the nature of the organic molecules that make up the dyes. Only for electrode E1 the mineralization efficiency of organic compounds present in the dye solution increased with increasing the applied current density. For electrode E1, using highest value of current density $(200 \mathrm{~mA}$ $\mathrm{cm}^{-2}$ ), the TOC value of the initial solution was $37.84 \mathrm{mg} \mathrm{L}^{-1}$ and after $90 \mathrm{~min}$ of treatment this value decreased to $21.71 \mathrm{mg} \mathrm{L}^{-1}$, which corresponds $45 \%$ of a removal of the organic matter. The electrode E2 did not remove the organic matter present in the RO16 dye solutions. This result further highlights the better efficiency of the BDD electrode for this application. 
The difference in the efficiency of electrooxidation can be explained by the two behaviors. Comninellis (23) explained the behavior of different electrodes in the electrochemical oxidation of organic compounds, considering two extreme cases: for active and non-active electrodes. As BDD electrodes are classified as non-active, their mechanism of degradation starts with surface water discharge anode (M) to produce hydroxyl radicals:

$$
\mathrm{M}+\mathrm{H}_{2} \mathrm{O} \rightarrow \mathrm{M}(\cdot \mathrm{OH})+\mathrm{H}^{+}+\mathrm{e}^{-}
$$

These radicals are weakly adsorbed on the electrode surface and are considered almost free radicals and have a high oxidation power. The mineralization process is as follows:

$$
\mathrm{BDD}(\cdot \mathrm{OH})+\mathrm{R} \rightarrow \mathrm{DDB}+\text { mineralized products }+\mathrm{H}^{+}+\mathrm{e}^{-}
$$

In addition, BDD has a high overpotential for the evolution of $\mathrm{O}_{2}$ and it is directly related to the weak interaction of $\bullet \mathrm{OH}$ radicals on the electrode surface.

The DSA electrode, classified as active, participates in the oxidation of organic matter. After the water discharge, the hydroxyl radicals, generated from the oxidation process, are strongly adsorbed on the anode surface and participates of the higher oxides $\left(\mathrm{MO}_{\mathrm{x}+1}\right)$ formation:

$$
\left(\mathrm{MO}_{\mathrm{x}}\right)+\mathrm{H}_{2} \mathrm{O} \rightarrow\left(\mathrm{MO}_{\mathrm{x}+1}\right)+2 \mathrm{H}^{+}+2 \mathrm{e}^{-}
$$

Thus, the $\left(\mathrm{MO}_{\mathrm{x}+1}\right)$ is responsible for the oxidation of organic matter and for the evolution of $\mathrm{O}_{2}$ according to Equations 4 and 6 [25]:

$$
\begin{gathered}
\left(\mathrm{MO}_{\mathrm{x}+1}\right)+\mathrm{R} \rightarrow\left(\mathrm{MO}_{\mathrm{x}}\right)+\mathrm{RO} \\
\left(\mathrm{MO}_{\mathrm{x}+1}\right) \rightarrow\left(\mathrm{MO}_{\mathrm{x}}\right)+1 / 2 \mathrm{O}_{2}
\end{gathered}
$$

This oxidation is partial and selective. The species $\left(\mathrm{MO}_{\mathrm{x}+1}\right)$ is continuously regenerated and these electrodes have a low overpotential for the reaction of oxygen release. As a consequence, the mechanism above described confirms the better efficiency of the BDD electrode to decreases the concentration of the RO16 dye and to mineralizes the organic matter present in the solutions, compared to those for the commercial DSA$\mathrm{Cl}_{2}{ }^{\circledR}$ electrode. 


\section{HPLC Qualitative Detection}

The aromatic intermediates produced during each electrochemical treatment containing RO16 dye were detected by high performance liquid chromatography (HPLC) using a wavelength of $254 \mathrm{~nm}$. The appearance of chromatographic signal at $254 \mathrm{~nm}$ is related to the $\pi-\pi *$ transition of the conjugated systems, such as aromatic compounds that make up the solution of the RO16 dye. Figure 4 shows the chromatograms of solutions containing RO16 dye untreated (1) and the solutions after electrolysis at current density of $200 \mathrm{~mA} \mathrm{~cm}^{-2}: 10 \mathrm{~min}$ (2) $90 \mathrm{~min}$ (3), using E1 and E2 electrodes, respectively. For the untreated dye solution (chromatogram 1), at least six aromatic compounds appeared, with different polarities and retention times, named in the chromatograms as peaks from A to $\mathrm{F}$. The compounds concerning peaks D and F, by their proportion, should be directly associated with the reactive RO16 dye. After the electrochemical treatment in the first $10 \mathrm{~min}$ at $200 \mathrm{~mA} \mathrm{~cm}^{-2}$ (chromatogram 2), using the electrode E1, a decrease of two main peaks related to the dye (D and F) is observed. Nevertheless, using the electrode E2, at the same treatment time, these two peaks are still evident. After 90 min of treatment there is the appearance of other peaks with lower retention time in chromatograms of both electrodes in the study. These peaks would imply the presence of more polar compounds than the dye under study. For electrode E1 the peaks D and F completely disappeared after 90 min of treatment while for electrode E2 they were kept evident. This result confirms the highest efficiency to degrade RO16 dye using the BDD electrode.
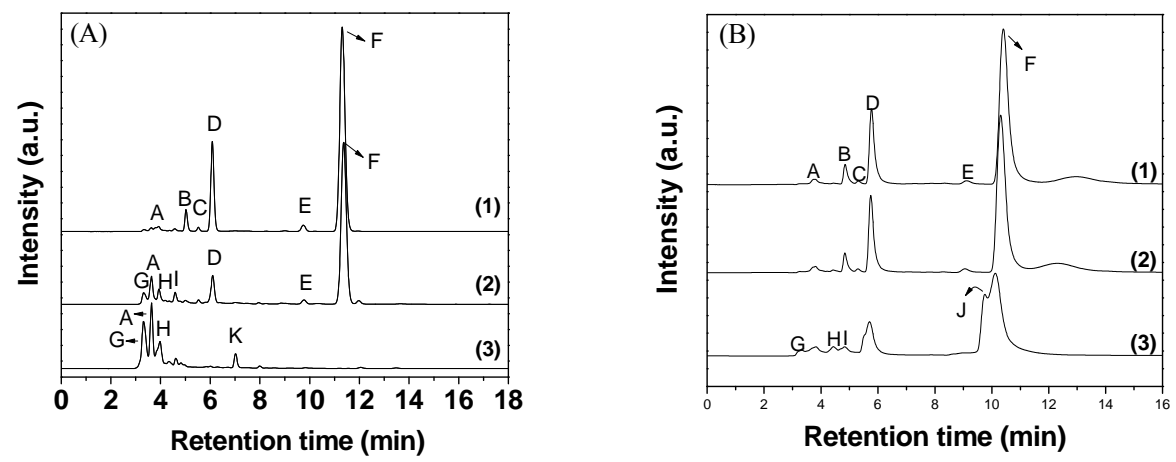

Figure 4. Chromatograms of RO16 dye samples obtained with a current density of 200 $\mathrm{mAcm}^{-2}$ with the electrodes (A) BDD and (B) DSA-Cl ${ }_{2}{ }^{\circledR}$ for the times: (1) 0 min, (2) 10 min and (3) $90 \mathrm{~min}$.

\section{Conclusion}

The BDD electrode was effective in the process of electrochemical degradation of the solution containing the RO16 dye. It presented high performance considering the complete removal of the solution color, the TOC removal, and the degradation of aromatic compounds. The diamond electrode was more efficient for all current densities studied compared with DSA-Cl${ }_{2}{ }^{\circledR}$ type electrode. 


\section{Acknowledgments}

The authors gratefully acknowledge the financial support provided by FAPESP (2010/18462-2), CNPq and CAPES.

\section{References}

1. W. F. JARDIM, Revista de Química Industrial, 692, 16-18 (1993).

2. M. V. SPERLING, Water Science and Technology, 33, 59-72 (1996).

3. L.D Santos, J.C. Afonso, A.J.B. Dutra, Separation and Purification Technology, 76, 151-157 (2010).

4. Z. François, P. Drogui, J.F. Blais, G. Mercier, P. Lafrance, Journal of Hazardous Materials, 185, 1499-1507 (2011).

5. O. Simond, V. Schaller, C. Comninellis, Electrochemica Acta, 42, 2009-2012 (1997).

6. G.R.P. Malpass, D.W. Miwa, S.A.S. Machado, P. Olivi, A.J. Motheo, Journal of Hazardous Materials, 137, 565-572 (2006).

7. L. Du, Y. Wang, S. Dai, J. Pei, S. Qin, C .Hu, Journal of Hazardous Materials, 185, 1596-1599 (2011).

8. E. Kusmierek, E. Chrzescijanska, M. Szadkowska-Nicze, Kaluzna-Czaplinska, Journal Applied Electrochemistry, 41, 51-62 (2011).

9. B. Marselli, J. Garcia-Gomez, P.A. Michaud, M.A. Rodrigo, C. Comninellis, Journal of the Electrochemical Society, 150, 79-83 (2003).

10. Y.V. Pleskov, A.Y. Sakharova, M.D. Krotova, Journal of Electroanalytical Chemistry, 228, 19-27 (1987).

11. V. Santos, J. Diogo, M.J.A. Pacheco, L. Ciríaco, A. Morão, A. Lopes, Chemosphere 79 637-645 (2010).

12. Y. Cuia, X. Lib, G. Chenc, Water Research, 43, 1968-1976 (2009).

13. X. Mao, F. Tian, F. Gan, A. Lin, X. Zhang, Russian Journal of Electrochemistry, 44, 802-811 (2008).

14. M. Panizza, G. Cerisola, Electrochimica Acta, 51, 191-199 (2005).

15. M. Panizza, A. Kapalka, C. Comninellis, Electrochimica Acta, 53, 2289-2295 (2008).

16. G. Ciardelli, N. Ranieri, Water Research, 35, 567-572 (2001).

17. H. M. Pinheiro, E. Touraud, E. Thomas, Dyes and Pigments, 61, 121-139 (2004).

18. N. A. Braga, C. A. A. Cairo, E. C. Almeida, M. R. Baldan, N. G. Ferreira, Diamond e Related Materials, 17, 1891-1896 (2008).

19. D.S. Knight, W.B. White, Journal Materials Research, 4, 385-393, 1989.

20. L.L.G. Silva, M.K. Franco, F. Yokaichiya, N.G. Ferreira, E.J. Corat, Diamond and Relatated Materials, 11, 153-159 (2002).

21. P.W. May, W.J. Ludlow, M. Hannaway, P.J. Heard, J.A. Smith, K.N. Rosser, Diamond and Relatated Materials, 17, 105-117 (2008).

22. P. Atkins, J. Loretta, Princípios de química: questionando a vida moderna e o meio ambiente. Tradução Ricardo Bicca de Alencastro, $3^{\mathrm{a}}$ ed., p. 588, Porto alegre: Bookman (2006).

23. B. Marselli, J. Garcia-Gomez, P.A. Michaud, A. Rodrigo, C. Comninellis, Journal of the Electrochemical Society, 150, 79-83 (2003). 